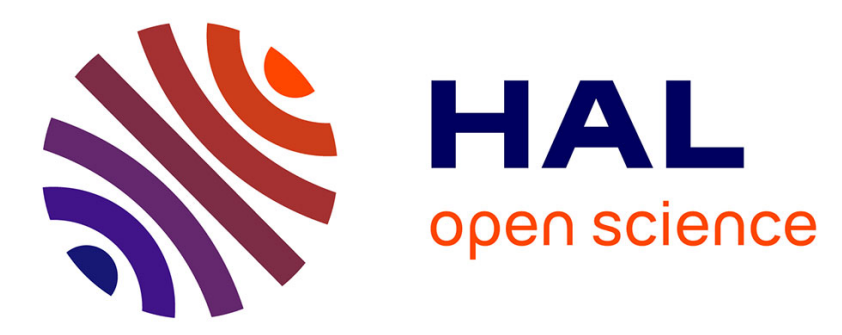

\title{
Reducing GABAergic inhibition restores cognitive functions in a mouse model of Down syndrome
}

\author{
M. C. Potier, J. Braudeau, L. Dauphinot, B. Delatour
}

\section{To cite this version:}

M. C. Potier, J. Braudeau, L. Dauphinot, B. Delatour. Reducing GABAergic inhibition restores cognitive functions in a mouse model of Down syndrome. CNS Neurol Disord Drug Targets, 2014, 13 (1), pp.8-15. 10.2174/18715273113126660185 . hal-03236877

\section{HAL Id: hal-03236877 \\ https://cnrs.hal.science/hal-03236877}

Submitted on 26 May 2021

HAL is a multi-disciplinary open access archive for the deposit and dissemination of scientific research documents, whether they are published or not. The documents may come from teaching and research institutions in France or abroad, or from public or private research centers.
L'archive ouverte pluridisciplinaire HAL, est destinée au dépôt et à la diffusion de documents scientifiques de niveau recherche, publiés ou non, émanant des établissements d'enseignement et de recherche français ou étrangers, des laboratoires publics ou privés. 
Title: REDUCING GABAERGIC INHIBITION RESTORES COGNITIVE FUNCTIONS IN A MOUSE MODEL OF DOWN SYNDROME.

Running title: GABA antagonism as a therapy for Down syndrome

Authors: Marie-Claude Potier ${ }^{1 *}$, Jérôme Braudeau ${ }^{1}$, Luce Dauphinot ${ }^{1}$, Benoît Delatour ${ }^{1}$

Affiliations: Centre de Recherche de l'Institut du Cerveau et de Moelle Epinière, CNRS UMR7225, INSERM UMRS 975, UPMC, ICM, Hôpital Pitié-Salpêtrière, Paris, France.

*Corresponding author:

Dr. Marie-Claude POTIER

ICM

Hôpital Pitié-Salpêtrière

CNRS UMR7225, INSERM UMRS975, UPMC

47, Bd de l'Hôpital

75013 PARIS, FRANCE

$+33157274519$

marie-claude.potier@upmc.fr 


\begin{abstract}
:
Alterations in excitatory-inhibitory balance occur in Down syndrome and could be responsible for cognitive deficits observed through the life of all individuals carrying an extra copy of chromosome 21 . Excess of inhibition in the adult could produce synaptic plasticity deficits that may be a primary mechanism contributing to learning and memory impairments. In this study we discuss pharmacological treatments that could potentially alleviate neuronal inhibition and have been tested in a mouse model of Down syndrome. $\gamma$-aminobutyric acid (GABA) is the major inhibitory neurotransmitter in the mature central nervous system that binds to GABAbenzodiazepine receptors, opens a chloride channel and reduces neuronal excitability. These receptors have been extensively studied as targets for treatment of epilepsy, anxiety, sleep, cognitive disorders and the induction of sedation. Molecules that are either antagonists or inverse agonists of the GABA-benzodiazepine receptors are able to reduce inhibitory GABAergic transmission. However modulating the excitatory-inhibitory balance towards increase of cognition without inducing seizures remains difficult particularly when using GABA antagonists. In this study we review data from the literature obtained using inverse agonists selective for the $\alpha 5$ subunit containing receptor. Such inverse agonists, initially developed as cognitive enhancers for treatment of memory impairments, proved to be very efficient in reversing learning and memory deficits in a Down syndrome mouse model after acute treatment.
\end{abstract}

Keywords: chloride, cognitive enhancer, Down syndrome, GABA, immediate early genes, inhibition 
Down syndrome (DS) is the most common genetic cause of intellectual disability (1/800 live births), and is the consequence of trisomy 21 [1]. Among all clinical features, DS is characterized by varying degrees of cognitive impairments [2]. The life expectancy of individuals with DS being now 55 years, treatments that would increase their autonomy and their quality of life need to be developed. Additionally since people with DS have Alzheimer's disease (AD) neuropathology in their early forties, several clinical trials have been or are being conducted with anticholinesterase drugs (Donepezil and Rivastagmine) that are largely prescribed in AD. Recently Duke University recruited adolescents with DS to evaluate the pro-cognitive effects of rivastigmine (referenced on http://clinicaltrials.gov).

Treating cognitive deficits is complex and multi-faceted and it is now accepted that polytherapies will be necessary to improve cognition of individuals with DS. For instance association of intermittent neuropharmacological intervention to constant teaching and educational methods might prove to be adequate to combat cognitive deficits.

\section{The GABA hypothesis in Down syndrome:}

A large number of studies have shown that cognitive impairment displayed by mouse models of DS is related to excessive levels of neuronal inhibition in the medial temporal lobe circuitry, causing a failure of memoryassociated long-term synaptic potentiation (LTP) in the hippocampus $[3,4]$. The deficit of synaptic plasticity translates into structural morphological changes and increased levels of synaptic proteins at hippocampal and cortical inhibitory synapses [5]. Excessive levels of inhibition thus appear essential in mouse models of DS but are probably not unique components of the physiopathology of this disorder. Particularly, the hypothesis needs conclusive results in DS individuals.

\section{GABA and its receptors: what is known and unknown in Down syndrome:}

\section{$\underline{\text { GABA levels }}$}

Inhibition in the adult forebrain is mainly controlled by one major inhibitory neurotransmitter, $\gamma$-aminobutyric acid (GABA). GABA is synthesized from the excitatory neurotransmitter glutamate, via the action of glutamate decarboxylase (GAD) enzymes, GAD65 and GAD67. Functionally, GABA-mediated inhibition can be classified as phasic (synaptic) and tonic (extrasynaptic). 
Levels of GABA in the brain of individuals with DS were measured postmortem using radioassay, chromatography, or in vivo using non invasive magnetic resonance spectroscopy (MRS). Postmortem studies have been conducted in adults with DS with AD-like neuropathology. Levels of GABA were found decreased in AD brains but globally unchanged in $\mathrm{DS}$ with $\mathrm{AD}$ [6]. A significant deficit of GABA has been reported in the hippocampus and in temporal cortex in individuals with DS carrying neocortical neurofibrillary tangles. These results are consistent with losses of cortical neurons containing these neurotransmitters, and resemble the deficits exhibited by the more severely affected cases of AD [7].

In the frontal cortex of fetuses with DS GABA levels were found to be reduced by $60 \%$ [8]. This large decrease could be related to the excitatory effects of GABA in immature neurons. The GABA shift from excitatory to inhibitory properties is due to a change in intracellular chloride concentration which is regulated by transporters: the $\mathrm{Na}-\mathrm{K}-\mathrm{Cl}$ cotransporter $1(\mathrm{NKCC} 1)$ that import chloride and the $\mathrm{K}-\mathrm{Cl}$ cotransporter $2(\mathrm{KCC} 2)$ that export it $[9,10]$, Figure.

MRS studies in children below 18 (3-17 years old) concluded to a decrease of GABA in the temporal lobes while no change could be identified in the frontal lobes [11, 12]. Gene expression profiles from the hippocampus of trisomic Ts65Dn mice, the best characterized mouse model of DS carrying three copies of chromosome 21 orthologous genes as well as additional three copies of non orthologous genes $[13,14]$ revealed that GABA synthesis enzymes GAD65 and GAD67 were unchanged as compared to euploids [15]. No change has been reported in the adult brain of DS individuals [16]. GAD67 immunoreactivity was found increased in the brain of Ts65Dn mice and this increase was attributed to the gain of calretinin inhibitory interneurons [17]. Moreover a significant increase in colocalization of GAD65 and the vesicular GABA transporter was reported in the fascia dentata of Ts65Dn mice [5].

\section{$\underline{\text { GABA receptors }}$}

In the central nervous system, GABA is produced and released by inhibitory interneurons and acts on two main classes of membrane-bound receptors: the ionotropic chrloride permeable $\mathrm{GABA}_{\mathrm{A}}$ receptors (ligand-gated $\mathrm{Cl}$ channels), and the metabotropic ( $\mathrm{G}$ protein-coupled) $\mathrm{GABA}_{\mathrm{B}}$ receptors. Recent research efforts unraveled the positive effects of $\mathrm{GABA}_{\mathrm{B}}$ receptors modulation for the treatment of cognitive impairments in Down syndrome $[18,19]$. However, the $\mathrm{GABA}_{\mathrm{A}}$ receptor family is the predominant type in the brain and has a long history for modulating learning and memory functions. GABA $\mathrm{G}_{\mathrm{A}}$ receptors are composed of five subunits $(\alpha 1-6 ; \beta 1-3 ; \gamma 1-3 ; \delta ; \varepsilon ; \theta ; \pi)$ that form a chloride channel. Each subunit has a transmembrane domain and carries binding sites for GABA and other modulators (benzodiazepines, barbiturates, pentylenetetrazol which are 
not endogenous modulators). In the adult brain, the chloride concentration is lower inside neuronal cells as compared to the extracellular compartment and GABA binding to its $\mathrm{GABA}_{\mathrm{A}}$ receptor leads to chloride influx. This leads to membrane hyperpolarization and subsequent inhibition of neuronal activity.

The subunit composition and the distribution of $\mathrm{GABA}_{\mathrm{A}}$ receptors mediating phasic and tonic inhibitions differ. Indeed phasic inhibition is mediated by low affinity $\mathrm{GABA}_{\mathrm{A}}$ receptors localized at the synapse, whereas tonic inhibition arises from activation of high affinity extrasynaptic receptors activated by lower concentrations of ambient GABA [20]. Extrasynaptic GABA receptors are more abundant than those found at synapses and have been suggested to sense GABA spillover.

Each subunit of $\mathrm{GABA}_{\mathrm{A}}$ receptors has a distinct regional and cellular distribution in the brain. Using in situ hybridization and immunohistochemistry, it was shown that the $\alpha 5$ subunit is mainly localized in the hippocampus, the neocortex and the olfactory bulb in rodents [21, 22]. In human using positron emission tomography (PET) and $\left[{ }^{11} \mathrm{C}\right]$ Ro $15-4513$ as a tracer that labels $\alpha 5-\mathrm{GABA}_{\mathrm{A}}$ receptors, it was shown that $\alpha 5$ subunit is abundant in the hippocampus, the cortex with an antero-posterior gradient and the nucleus accumbens as well as the olfactory bulb [23].

a5-containing $\mathrm{GABA}_{\mathrm{A}}$ receptors are concentrated in the dendrites of hippocampal cornu ammonis CA1 pyramidal neurons and play a role in regulating tonic inhibition through extrasynaptic receptors [24], Figure. A pool of $\alpha 5$-containing GABAA receptors has also been detected at GABAergic synapses on the dendrites of hippocampal pyramidal neurons and could modulate phasic GABAergic inhibition [25]. In the neocortex synapses innervated by bitufted GABAergic interneurons that are parvalbumin and cholecystokinin negative are sensitive to $\alpha 5$ IA [26].

In the absence of $\alpha 5$-containing $\mathrm{GABA}_{\mathrm{A}}$ receptors tonic inhibition of hippocampal CA1 and CA3 pyramidal cells is about half that found in the control situation, but phasic inhibition is unaltered. This specific reduction of tonic inhibition is sufficient to induce epileptiform activity in the CA3 region that could be reversed by increasing the tonic current [20]. $\alpha 5-\mathrm{GABA}_{\mathrm{A}}$ receptors would be recruited only when ambient GABA levels are increased.

Gene expression profiles from the hippocampus of adult Ts65Dn mice revealed that $\mathrm{GABA}_{\mathrm{A}}$ and $\mathrm{GABA}_{\mathrm{B}}$ receptor subunits were unchanged as compared to euploids [15]. In addition levels of GABA $\alpha 1, \beta 2$ and $\beta 3$ proteins were found to be unchanged in the hippocampus of adult Ts65Dn mice while the levels of GABAB receptors R2 were 19\% less. This decrease was attributed to compensatory mechanism in response to the increase of $\mathrm{G}$ protein coupled inward rectifier potassium channel 2 (GIRK2) levels, an inwardly rectifying potassium channel mapping to the trisomic region [27]. In another recently published study no change in 
$\mathrm{GABA}_{A}$ and $\mathrm{GABA}_{B}$ receptors could be identified [19]. However a $20 \%$ decrease of $\mathrm{GABA}_{\mathrm{A}} \beta 2$ and $\beta 3$ proteins was found in the dentate gyrus of Ts65Dn adult mice [28]. Finally Martinez-Fernandez et al. did not find any change in the binding of RO0154513, a selective $\mathrm{GABA}_{\mathrm{A}} \alpha 5$ inverse agonist, in vivo in Ts65Dn mice [29].

\section{GABA receptor ligands}

GABA competitive inhibitors antagonize the effects of GABA and thus increase neuronal activity eventually leading to epilepsy. Non competitive GABA antagonists also inhibit the effects of endogenous GABA through a binding site located at the proximity GABA binding site. Other ligands of the binding sites present on $\mathrm{GABA}_{\mathrm{A}}$ pentamers have been actively developed with the hope of finding new modulators of GABA transmission.

Administration of non-competitive antagonists of $\mathrm{GABA}_{\mathrm{A}}$ receptors (picrotoxin and pentylenetetrazol) were shown to reverse spatial learning disabilities and LTP deficits in DS mouse model suggesting the central role of over-inhibition in learning deficits of the Ts65Dn mice [30, 31].

Other ligands bind to GABA

Benzodiazepines synthesized in the 1960's are positive allosteric modulators (PAM) used for their anticonvulsant, anxiolytic, sedative and myorelaxant effects, as well as for the treatment of alcohol withdrawal syndrome. Benzodiazepines bind to $\mathrm{GABA}_{\mathrm{A}}$ receptors and increase GABA efficacy by an allosteric modulation thus increasing the opening frequency of channels and chloride flux, leading to stronger inhibition. Benzodiazepine agonists facilitate the action of GABA. They are positive allosteric modulators (PAM). Benzodiazepine antagonists reverse the effects of agonists but have no intrinsic activity on GABA transmission. Finally inverse agonists are competitive ligands of the benzodiazepine site that decrease GABA affinity thus reducing the action of GABA. They are negative allosteric modulators (NAM). They were shown to be convulsant, anxiogenic and promnesiant (increasing learning and memory) $[32,33]$. The $\beta$-carboline inverse agonist FG7142 turned to have anxiogenic properties that precluded its clinical development [34]. Ro15-4513 a partial inverse agonist developed by Hoffmann-La Roche has been used for blocking the effects of ethanol in the central nervous system [35]. The drug is still being used in positron emission tomography for imaging GABA receptors in humans and animals brains [23].

Since $\alpha 1, \alpha 2, \alpha 3$ and $\alpha 5$ subunits drive the sedative/anticonvulsant, anxiolytic and promnesiant actions respectively, an alternative strategy would be to develop molecules that are selective for these subtypes of receptors [36]. Knock-out mice for the $\alpha 5$ subunit show enhanced learning and memory [37]. In addition in knock-in mice carrying a point mutation invalidating the gene encoding the $\alpha 5$ subunit associative learning was 
facilitated [38]. For the promnesiant, more generally nootropic activity that translates into higher learning and memory performances, the pharmaceutical industry has searched for new ligands selective of the $\alpha 5$-containing $\mathrm{GABA}_{\mathrm{A}}$ receptors $[39,40]$. Several new series of molecules specific for the $\alpha 5$-containing $\mathrm{GABA}_{\mathrm{A}}$ receptors have been discovered that showed enhanced learning and memory properties in animal models: PWZ-029 [41] a triazolophtalazines $\alpha 5$ inverse agonist ( $\alpha 5 \mathrm{IA})$ from Merck laboratories [42-46] and more recently the triazolobenzodiazepine Ro4938581/RG1662 from Hoffmann-La Roche [47]. The $\alpha 5$ IA has a higher efficacy as a negative allosteric modulator of GABAergic transmission on the $\alpha 5$ subunit as compared to the $\alpha 1$ subunit and is a weak positive allosteric modulator on the $\alpha 2$ and the $\alpha 3$ subunit while affinities are nearly similar for all subunits $(0.88,0.68,0.61$ and $0.66 \mathrm{nM}$ for the $\alpha 1, \alpha 2, \alpha 3$ and $\alpha 5$ subunits respectively) [44]. Differently Ro4938581 has higher affinity for the $\alpha 5$-containing $\mathrm{GABA}_{\mathrm{A}}$ receptors $(4.6 \mathrm{nM})$ than for the $\alpha 1(174 \mathrm{nM})$ $\alpha 2(185 \mathrm{nM})$ and $\alpha 3$-containing $\mathrm{GABA}_{\mathrm{A}}$ receptors $(80 \mathrm{nM})$ and is a negative allosteric modulator of $\alpha 5$ containing $\mathrm{GABA}_{\mathrm{A}}$ receptors only [47]. Table 1 shows the in vivo comparative pharmacological profile of $\alpha 5 \mathrm{IA}$ and Ro4938581. The overall data indicate a lack of effect of the two drugs on anxiety-related behaviors and on convulsant/proconvulsant activity and most importantly promnesiant effects in different learning and memory paradigms. In humans at doses that are not anxiogenic $\alpha 5$ IA raised a receptor occupancy of $50 \%$ [48]

\section{$\underline{G A B A_{A}-\alpha 5}$ selective inverse agonists in $D S$}

After the publication of Fernandez et al. (2007) demonstrating that $\mathrm{GABA}_{\mathrm{A}}$ antagonists can stably reverse cognitive deficits in DS mouse models, we reasoned that $\mathrm{GABA}_{\mathrm{A}}-\alpha 5$ selective inverse agonists would act as negative allosteric modulators of GABAergic transmission and reduce inhibition as $\mathrm{GABA}_{\mathrm{A}}$ antagonists do. This would result in improved cognition in DS mice without deleterious convulsant effects of $\mathrm{GABA}_{\mathrm{A}}$ antagonists.

The triazolophtalazines from Merck being unavailable when requested, we resynthetized the $\alpha 5$ IA ( $\alpha 5$ inverse agonist) following the steps described in Chambers et al. (2004) [46] and in their patent (WO 98/50385). We then tested the $\alpha 5 \mathrm{IA}$ in the Ts65Dn mice in two learning and memory tasks: the Morris water maze (MWM) and the novel object recognition (NOR) that test respectively spatial reference memory (hippocampal-dependent) and short term non spatial memory which relies on parahippocampal cortical areas [49]. We showed that after acute treatment (single $5 \mathrm{mg} / \mathrm{kg}$ intra peritoneal i.p. dose before each training session) $\alpha 5 \mathrm{IA}$ can restore learning and memory deficits of Ts65Dn mice both in the MWM and the NOR tasks [50]. In the NOR task $\alpha 5$ IA also increased the performance of wt mice. Interestingly in the same task Ts65Dn mice treated with $\alpha 5$ IA not only recovered from their deficit but performed as well as treated wild type euploid (wt) mice. 
We showed that $\alpha 5$ IA has no convulsant nor proconvulsant activity in wt and Ts65Dn mice. Surprisingly we observed that the convulsant methyl $\beta$-carboline-3-carboxylate $(\beta-\mathrm{CCM})$ inverse agonist had no effect in Ts65Dn mice (while clearly inducing convulsant effects in euploid mice) suggesting that either $\beta$-CCM is metabolized differently in Ts65Dn mice or that it is not potent enough to counterpart the increased inhibition in DS mice possibly associated to higher levels of GABA (Table 2).

Locomotor activity is increased in Ts65Dn mice as compared to wt, and treatment did not modify this difference. In the elevated plus maze that evaluates anxiety, Ts65Dn were less anxious, spending more time in the open arms as compared to wt. However after $\alpha 5 \mathrm{IA}$ treatment $(15 \mathrm{mg} / \mathrm{kg}$, three fold higher than the active dose in MWM and NOR), Ts65Dn and wt mice performed equally, indicating that $\alpha 5$ IA does not show anxiogenic activity. Two main questions remain to be answered: i) what would be the effects of chronic injections of $\alpha 5$ IA? ii) are the promnesiant effects long lasting? iii) what would be the effects of $\alpha$ IA in mouse models carrying full trisomy 21 ?

Since the promnesiant effects observed in Ts65Dn mice after $\alpha 5$ IA treatment were dose-dependent, we hypothesized that $\alpha 5 \mathrm{IA}$ acted through binding to $\alpha 5$-containing $\mathrm{GABA}_{\mathrm{A}}$ receptors and decreased GABAergic transmission. We could not find any difference between the amounts of $\alpha 5$ transcripts in Ts65Dn and in wt brains [15]. Comparing electrophysiological properties of $\alpha 5 \mathrm{IA}$ in Ts65Dn and wt mice will be necessary in order to test whether structural/functional changes occur in the $\mathrm{GABA}_{\mathrm{A}}$ receptor subunits. Recently MartinezFernandez et al. reported that Ro4938581, the negative $\alpha 5$-containing $\mathrm{GABA}_{\mathrm{A}}$ allosteric modulator from Hoffmann La Roche was also able to rescue LTP and cognitive deficits of Ts65Dn thus validating our initial results with a structurally different ligand [29].

Changes in gene expression after chronic treatment with $\alpha 5$ IA:

In order to get insights into the mode of action of $\alpha 5$ IA in vivo we first investigated the expression of the murine osteosarcoma viral oncogene homolog fos protein, an immediate early gene (IEG) activated following behavioral stimulation. The fos protein (as well as other immediate early genes products) is hence classically used to map evoked neuronal activity $[51,52]$. We showed that fos translation triggered by a behavioral episode (exploration of a new environment) is strongly increased after treatment with $\alpha 5$ IA both in Ts65Dn and wt mice in the cortex, the CA1 region of the hippocampus but not in the dentate gyrus that lacks high density of $\alpha 5$-containing $\mathrm{GABA}_{\mathrm{A}}$ receptors. We then established gene expression profiles of Ts65Dn and wt hippocampi collected after chronic 
treatment (during 12 days) with $\alpha 5$ IA and compared expression levels to vehicle-treated mice. We analyzed separately the three-copy genes and the immediate early genes. Three triplicated genes were found to be differentially expressed between Ts65Dn and wt mice and among them the superoxide dismutase 1 (Sod1) gene which has been shown to participate in several clinical features of DS [15]. Interestingly $\alpha 5$ IA treatment corrected the elevated levels of Sod1 present in Ts65Dn mice. It will be important to test whether Sod1 could be a marker of $\alpha 5$ IA efficiency in vivo.

In euploid mice, chronic treatment with $\alpha 5$ IA increased IEGs expression, particularly of c-Fos and the activityregulated cytoskeleton-associated protein (Arc) genes. In Ts65Dn mice, deficits of IEGs activation particularly of c-Fos and early growth response 2 (Egr2) were rescued after treatment with $\alpha 5$ IA but did not reach the levels obtained after $\alpha 5$ IA treatment of wt mice. At the protein level we could not find any deficit of fos basal levels between Ts65Dn and wt mice. Differences between the two analysis at the protein and at the transcript levels could be explained in various ways: i) transcripts were analyzed after training the mice in the MWM task during two weeks while Fos immunoreactivity was measured after the short-lasting exploration-memorization of a new environment ii) transcripts were quantified after 12 days of treatment while for Fos immunoreactivity, acute treatment was applied. Analysis at the transcript and at the protein levels will need to be performed after similar behavioral stimulation and equivalent treatment regimen to reach conclusion.

Increased activation of IEGs could allow a more efficient storage of information during memory process and correct deficits in learning and memory functions that have been described in DS.

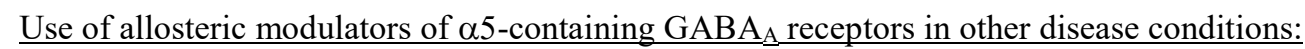

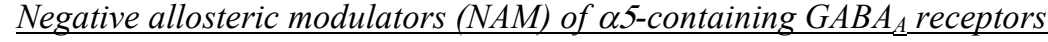

As a general cognitive enhancer and GABAergic inhibitor, $\alpha 5$ IA could be a target for increasing cognition not only in the normal brain but also in memory-challenging conditions and in neuropsychiatric disorders [53]. Indeed we found that $\alpha 5$ IA can reverse cognitive deficits in a mouse model of DS without showing any adverse effects. Another study by Nutt et al. has shown the benefits of GABA 25 -inverse agonists for treating alcoholinduced amnesia in human [54].

After stroke in mice, tonic inhibition is increased in the peri-infarct zone; it is mediated by extra synaptic $\mathrm{GABA}_{\mathrm{A}}$ receptors and caused by an impairment for GABA transporter function. This over inhibition could be alleviated using $\alpha 5 \mathrm{IA}$ as well as by lowering the number of $\alpha 5$-containing $\mathrm{GABA}_{\mathrm{A}}$ receptors [55]. 
Inhalation of anesthetics promotes anterograde amnesia. It was recently shown that $\alpha 5$-containing $\mathrm{GABA}_{\mathrm{A}}$ receptors are necessary for the development of post-anesthetic deficits in recognition [56]. These receptors could thus be targeted to restore memory even after elimination of the anesthetic.

\section{Positive allosteric modulators (PAM) of $\alpha 5$-containing GABA $\underline{A}_{\text {receptors }}$}

Excessive neuronal activity in the hippocampus has been shown to contribute to cognitive impairment in aging. In aged rats with cognitive impairment, pyramidal neurons of the dentate gyrus have elevated excitability [57]. Moreover, aberrant excitability is found in the hippocampus of transgenic mice overexpressing amyloid precursor protein [58] and in mouse model expressing the $\varepsilon 4$ allelle of the apolipoprotein E (ApoE4) that confers elevated risk for sporadic Alzheimer's disase [59]. In aged rats, the positive allosteric modulators of $\alpha 5$ containing $\mathrm{GABA}_{\mathrm{A}}$ receptors, the thiophene derivatives developed initially by Merck $[45,60]$, produced memory improvements thus suggesting a novel approach to improve neural function in clinical conditions of abnormal (increased) hippocampal activity [61]. Also the use of levetiracetam, an antiepileptic drug, has been shown to mitigate neuronal hyperactivity in subjects with mild cognitive impairments (a condition at risk for conversion to $\mathrm{AD)}$ and to improve memory performance [62].

\section{Modulating chloride ions flux in disease conditions}

The symptoms of autism spectrum disorders (ASDs) are the result of deficient GABA neurotransmission and higher intracellular chloride concentrations leading to brain hyper excitability early during brain development [63]. Initial evidence of a deficit in $\alpha 5$-containing $\mathrm{GABA}_{\mathrm{A}}$ receptors in $\mathrm{ASD}$ has been shown and support further investigations of the GABA system in this disorder [64]. Interestingly it was recently found that Bumetanide, an inhibitor of the chloride co-transporter NKCC1 that reduces intracellular chloride concentration, produced a significant improvement in infantile autistic syndrome without any side effects [65].

\section{Conclusions:}

In DS GABA over inhibition has not been associated to the over expression of specific genes mapping to human chromosome 21. Over inhibition could be a secondary event leading to neural plasticity defects. Yet the amounts of GABA synthesis enzymes (GAD) and chloride co-transporters (NKCC1 and KCC2) need to be measured in this disease. In addition levels of GABA can now be assessed in vivo before and after treatments using MRS [6668]. These new protocols could be applied in DS individuals as well as in mouse models.

Many GABA mimetics are widely used in clinic: they either increase GABA transaminase, glutamate decarboxylase or inhibit GABA reuptake. Unfortunately drugs that would have opposite effects may induce 
hyper excitability. Still the effects of drugs acting on the cation-chloride co-transporters (activator of NKCC1 or inhibitor of KCC2) remain to be demonstrated in DS mouse models (Figure).

At the present time, diminishing $\mathrm{GABA}_{\mathrm{A}}$ inhibition in DS with negative allosteric modulators of the $\alpha 5$ containing $\mathrm{GABA}_{\mathrm{A}}$ receptors appears as a sensible strategy since two molecules of this class have already proven to be very efficient for correcting cognitive deficits in DS mouse models and one currently being tested in DS individuals [69]. 
Acknowledgments:

The authors wish to thank the Fondation AMIPI-Bernard Vendre, the AnEUploidy program (LSHG-CT-2006037627) and the Fondation Jérôme Lejeune for their financial support. They also wish to thank Dr. Nicole Ropert for fruitful discussions and for reading the manuscript, Dr. Richard Miles for discussions and Niels Lan Doky for the music.

List of abbreviations:

AD Alzheimer's disease

$\alpha 5$ IA $\alpha 5$ inverse agonist

ApoE apolipoprotein E

Arc activity-regulated cytoskeleton-associated protein

ASD autism spectrum disorder

$\beta$-CCM methyl $\beta$-carboline -3-carboxylate

CA1 cornu ammonis 1

DS Down syndrome

Egr2 early growth response 2

Fos murine osteosarcoma viral oncogene homolog

GABA raminobutyric acid

GAD glutamate decarboxylase

GIRK2 G protein coupled inward rectifier potassium channel 2

IEG an immediate early gene

i.p. intra peritoneal

$\mathrm{KCC} 2 \mathrm{~K}-\mathrm{Cl}$ cotransporter 2

MRS magnetic resonance spectroscopy

MWM Morris water maze

NAM Negative allosteric modulators

NKCC1 Na-K-Cl cotransporter 1

NOR the novel object recognition

PAM Positive allosteric modulators

PET positron emission tomography

Sod1 superoxide dismutase 1 


\section{Conflict of Interest}

The authors declare no conflict of interest 
[1] Lejeune J, Turpin R, Gautier M. [Mongolism; a chromosomal disease (trisomy)]. Bull Acad Natl Med 1959;143:256-65.

[2] Sherman SL, Allen EG, Bean LH, Freeman SB. Epidemiology of Down syndrome. Ment Retard Dev Disabil Res Rev 2007;13:221-7.

[3] Kleschevnikov AM, Belichenko PV, Villar AJ, Epstein CJ, Malenka RC, Mobley WC. Hippocampal long-term potentiation suppressed by increased inhibition in the Ts65Dn mouse, a genetic model of Down syndrome. J Neurosci 2004;24:8153-60.

[4] Siarey RJ, Carlson EJ, Epstein CJ, Balbo A, Rapoport SI, Galdzicki Z. Increased synaptic depression in the Ts65Dn mouse, a model for mental retardation in Down syndrome. Neuropharmacology 1999;38:1917-20.

[5] Belichenko PV, Kleschevnikov AM, Masliah E, Wu C, Takimoto-Kimura R, Salehi A, et al. Excitatory-inhibitory relationship in the fascia dentata in the Ts65Dn mouse model of Down syndrome. J Comp Neurol 2009;512:453-66.

[6] Seidl R, Cairns N, Singewald N, Kaehler ST, Lubec G. Differences between GABA levels in Alzheimer's disease and Down syndrome with Alzheimer-like neuropathology. Naunyn Schmiedebergs Arch Pharmacol 2001;363:139-45.

[7] Reynolds GP, Warner CE. Amino acid neurotransmitter deficits in adult Down's syndrome brain tissue. Neurosci Lett 1988;94:224-7.

[8] Whittle N, Macdonald W, Bailey S. A Study of Young Offenders' Perceptions of Health and Health Care Services in Custody and in the Community. J Correct Health Care 2012.

[9] Ben-Ari Y, Khalilov I, Kahle KT, Cherubini E. The GABA Excitatory/Inhibitory Shift in Brain Maturation and Neurological Disorders. Neuroscientist 2012.

[10] Miles R, Blaesse P, Huberfeld G, Wittner L, Kaila K. Chloride homeostasis and GABA signaling in temporal lobe epilepsy. 2012.

[11] Smigielska-Kuzia J, Bockowski L, Sobaniec W, Kulak W, Sendrowski K. Amino acid metabolic processes in the temporal lobes assessed by proton magnetic resonance spectroscopy $(1 \mathrm{H}$ MRS) in children with Down syndrome. Pharmacol Rep 2010;62:1070-7.

[12] Smigielska-Kuzia J, Sobaniec W. Brain metabolic profile obtained by proton magnetic resonance spectroscopy HMRS in children with Down syndrome. Adv Med Sci 2007;52 Suppl 1:183-7.

[13] Duchon A, Raveau M, Chevalier C, Nalesso V, Sharp AJ, Herault Y. Identification of the translocation breakpoints in the Ts65Dn and Ts1Cje mouse lines: relevance for modeling Down syndrome. Mamm Genome 2011;22:674-84.

[14] Reeves RH, Irving NG, Moran TH, Wohn A, Kitt C, Sisodia SS, et al. A mouse model for Down syndrome exhibits learning and behaviour deficits. Nat Genet 1995;11:177-84.

[15] Braudeau J, Dauphinot L, Duchon A, Loistron A, Dodd RH, Herault Y, et al. Chronic Treatment with a Promnesiant GABA-A alpha5-Selective Inverse Agonist Increases Immediate Early Genes Expression during Memory Processing in Mice and Rectifies Their Expression Levels in a Down Syndrome Mouse Model. Adv Pharmacol Sci 2011;2011:153218.

[16] Lockstone HE, Harris LW, Swatton JE, Wayland MT, Holland AJ, Bahn S. Gene expression profiling in the adult Down syndrome brain. Genomics 2007;90:647-60.

[17] Perez-Cremades D, Hernandez S, Blasco-Ibanez JM, Crespo C, Nacher J, Varea E. Alteration of inhibitory circuits in the somatosensory cortex of Ts65Dn mice, a model for Down's syndrome. J Neural Transm 2010;117:445-55.

[18] Kleschevnikov AM, Belichenko PV, Faizi M, Jacobs LF, Htun K, Shamloo M, et al. Deficits in cognition and synaptic plasticity in a mouse model of Down syndrome ameliorated by GABAB receptor antagonists. J Neurosci 2012;32:9217-27.

[19] Kleschevnikov AM, Belichenko PV, Gall J, George L, Nosheny R, Maloney MT, et al. Increased efficiency of the GABAA and GABAB receptor-mediated neurotransmission in the Ts65Dn mouse model of Down syndrome. Neurobiol Dis 2012;45:683-91. 
[20] Glykys J, Mody I. Hippocampal network hyperactivity after selective reduction of tonic inhibition in GABA A receptor alpha5 subunit-deficient mice. J Neurophysiol 2006;95:2796807.

[21] Fritschy JM, Mohler H. GABAA-receptor heterogeneity in the adult rat brain: differential regional and cellular distribution of seven major subunits. J Comp Neurol 1995;359:154-94.

[22] Laurie DJ, Wisden W, Seeburg PH. The distribution of thirteen GABAA receptor subunit mRNAs in the rat brain. III. Embryonic and postnatal development. J Neurosci 1992;12:415172.

[23] Lingford-Hughes A, Hume SP, Feeney A, Hirani E, Osman S, Cunningham VJ, et al. Imaging the GABA-benzodiazepine receptor subtype containing the alpha5-subunit in vivo with [11C]Ro15 4513 positron emission tomography. J Cereb Blood Flow Metab 2002;22:878-89.

[24] Caraiscos VB, Elliott EM, You-Ten KE, Cheng VY, Belelli D, Newell JG, et al. Tonic inhibition in mouse hippocampal CA1 pyramidal neurons is mediated by alpha5 subunit-containing gamma-aminobutyric acid type A receptors. Proc Natl Acad Sci U S A 2004;101:3662-7.

[25] Serwanski DR, Miralles CP, Christie SB, Mehta AK, Li X, De Blas AL. Synaptic and nonsynaptic localization of GABAA receptors containing the alpha5 subunit in the rat brain. J Comp Neurol 2006;499:458-70.

[26] Ali AB, Thomson AM. Synaptic alpha 5 subunit-containing GABAA receptors mediate IPSPs elicited by dendrite-preferring cells in rat neocortex. Cereb Cortex 2008;18:1260-71.

[27] Best TK, Cramer NP, Chakrabarti L, Haydar TF, Galdzicki Z. Dysfunctional hippocampal inhibition in the Ts65Dn mouse model of Down syndrome. Exp Neurol 2012;233:749-57.

[28] Belichenko PV, Kleschevnikov AM, Masliah E, Wu C, Takimoto-Kimura R, Salehi A, et al. Excitatory-inhibitory relationship in the fascia dentata in the Ts65Dn mouse model of Down syndrome. Journal of Comparative Neurology 2009;512:453-66.

[29] Martínez Fernández P. RN, Vidal R., García S., Vidal V., Corrales A., Florez J., Pazos A., Gasser R., Thomas A.W., Honer M., Knoflach F., Wettstein J.W., Martínez-Cue C. and Hernandez M. C. . R04938581, a selective GABAA a5 negative allosteric modulator, rescues LTP and cognition deficits in a mouse model of Down Syndrome. FENS 2012, Barcelona 2012.

[30] Fernandez F, Morishita W, Zuniga E, Nguyen J, Blank M, Malenka RC, et al. Pharmacotherapy for cognitive impairment in a mouse model of Down syndrome. Nat Neurosci 2007;10:411-3.

[31] Rueda N, Florez J, Martinez-Cue C. Chronic pentylenetetrazole but not donepezil treatment rescues spatial cognition in Ts65Dn mice, a model for Down syndrome. Neurosci Lett 2008;433:22-7.

[32] Venault P, Chapouthier G. From the behavioral pharmacology of beta-carbolines to seizures, anxiety, and memory. ScientificWorldJournal 2007;7:204-23.

[33] Venault P, Chapouthier G, Simiand J, Dodd RH, Rossier J. Enhancement of performance by methyl beta-carboline-3-carboxylate, in learning and memory tasks. Brain Res Bull 1987;19:365-70.

[34] Dorow R, Horowski R, Paschelke G, Amin M. Severe anxiety induced by FG 7142, a betacarboline ligand for benzodiazepine receptors. Lancet 1983;2:98-9.

[35] Suzdak PD, Glowa JR, Crawley JN, Schwartz RD, Skolnick P, Paul SM. A selective imidazobenzodiazepine antagonist of ethanol in the rat. Science 1986;234:1243-7.

[36] Mohler H. The rise of a new GABA pharmacology. Neuropharmacology 2011;60:1042-9.

[37] Collinson N, Kuenzi FM, Jarolimek W, Maubach KA, Cothliff R, Sur C, et al. Enhanced learning and memory and altered GABAergic synaptic transmission in mice lacking the alpha 5 subunit of the GABAA receptor. J Neurosci 2002;22:5572-80.

[38] Crestani F, Keist R, Fritschy JM, Benke D, Vogt K, Prut L, et al. Trace fear conditioning involves hippocampal alpha5 GABA(A) receptors. Proc Natl Acad Sci U S A 2002;99:8980-5.

[39] D'Hulst C, Atack JR, Kooy RF. The complexity of the GABAA receptor shapes unique pharmacological profiles. Drug Discov Today 2009;14:866-75.

[40] Uusi-Oukari M, Korpi ER. Regulation of $G A B A(A)$ receptor subunit expression by pharmacological agents. Pharmacol Rev 2010;62:97-135. 
[41] Savic MM, Clayton T, Furtmuller R, Gavrilovic I, Samardzic J, Savic S, et al. PWZ-029, a compound with moderate inverse agonist functional selectivity at $\operatorname{GABA}(\mathrm{A})$ receptors containing alpha5 subunits, improves passive, but not active, avoidance learning in rats. Brain Res 2008;1208:150-9.

[42] Collinson N, Atack JR, Laughton P, Dawson GR, Stephens DN. An inverse agonist selective for alpha5 subunit-containing GABAA receptors improves encoding and recall but not consolidation in the Morris water maze. Psychopharmacology (Berl) 2006;188:619-28.

[43] Dawson GR, Maubach KA, Collinson N, Cobain M, Everitt BJ, MacLeod AM, et al. An inverse agonist selective for alpha5 subunit-containing GABAA receptors enhances cognition. J Pharmacol Exp Ther 2006;316:1335-45.

[44] Sternfeld F, Carling RW, Jelley RA, Ladduwahetty T, Merchant KJ, Moore KW, et al. Selective, orally active gamma-aminobutyric acidA alpha5 receptor inverse agonists as cognition enhancers. J Med Chem 2004;47:2176-9.

[45] Chambers MS, Atack JR, Broughton HB, Collinson N, Cook S, Dawson GR, et al. Identification of a novel, selective $\mathrm{GABA}(\mathrm{A})$ alpha5 receptor inverse agonist which enhances cognition. J Med Chem 2003;46:2227-40.

[46] Chambers MS, Atack JR, Carling RW, Collinson N, Cook SM, Dawson GR, et al. An orally bioavailable, functionally selective inverse agonist at the benzodiazepine site of GABAA alpha5 receptors with cognition enhancing properties. J Med Chem 2004;47:5829-32.

[47] Ballard TM, Knoflach F, Prinssen E, Borroni E, Vivian JA, Basile J, et al. RO4938581, a novel cognitive enhancer acting at GABAA alpha5 subunit-containing receptors. Psychopharmacology (Berl) 2009;202:207-23.

[48] Eng W, Atack JR, Bergstrom M, Sanabria S, Appel L, Dawson GR, et al. Occupancy of human brain $\operatorname{GABA}(\mathrm{A})$ receptors by the novel alpha5 subtype-selective benzodiazepine site inverse agonist alpha5IA as measured using [(1)(1)C]flumazenil PET imaging. Neuropharmacology 2010;59:635-9.

[49] Steckler T, Drinkenburg WH, Sahgal A, Aggleton JP. Recognition memory in rats--II. Neuroanatomical substrates. Prog Neurobiol 1998;54:313-32.

[50] Braudeau J, Delatour B, Duchon A, Pereira PL, Dauphinot L, de Chaumont F, et al. Specific targeting of the GABA-A receptor alpha5 subtype by a selective inverse agonist restores cognitive deficits in Down syndrome mice. J Psychopharmacol 2011;25:1030-42.

[51] Guzowski JF, Timlin JA, Roysam B, McNaughton BL, Worley PF, Barnes CA. Mapping behaviorally relevant neural circuits with immediate-early gene expression. Curr Opin Neurobiol 2005;15:599-606.

[52] Tischmeyer W, Grimm R. Activation of immediate early genes and memory formation. Cell Mol Life Sci 1999;55:564-74.

[53] Wallace TL, Ballard TM, Pouzet B, Riedel WJ, Wettstein JG. Drug targets for cognitive enhancement in neuropsychiatric disorders. Pharmacol Biochem Behav 2011;99:130-45.

[54] Nutt DJ, Besson M, Wilson SJ, Dawson GR, Lingford-Hughes AR. Blockade of alcohol's amnestic activity in humans by an alpha5 subtype benzodiazepine receptor inverse agonist. Neuropharmacology 2007;53:810-20.

[55] Clarkson AN, Huang BS, Macisaac SE, Mody I, Carmichael ST. Reducing excessive GABAmediated tonic inhibition promotes functional recovery after stroke. Nature 2010;468:305-9.

[56] Zurek AA, Bridgwater EM, Orser BA. Inhibition of alpha5 gamma-Aminobutyric acid type A receptors restores recognition memory after general anesthesia. Anesth Analg 2012;114:845-55.

[57] Patrylo PR, Williamson A. The effects of aging on dentate circuitry and function. Prog Brain Res 2007;163:679-96.

[58] Palop JJ, Chin J, Roberson ED, Wang J, Thwin MT, Bien-Ly N, et al. Aberrant excitatory neuronal activity and compensatory remodeling of inhibitory hippocampal circuits in mouse models of Alzheimer's disease. Neuron 2007;55:697-711. 
[59] Andrews-Zwilling Y, Bien-Ly N, Xu Q, Li G, Bernardo A, Yoon SY, et al. Apolipoprotein E4 causes age- and Tau-dependent impairment of GABAergic interneurons, leading to learning and memory deficits in mice. J Neurosci 2010;30:13707-17.

[60] Atack JR. GABAA receptor subtype-selective modulators. II. alpha5-selective inverse agonists for cognition enhancement. Curr Top Med Chem 11:1203-14.

[61] Koh MT, Rosenzweig-Lipson S, Gallagher M. Selective GABA(A) alpha5 positive allosteric modulators improve cognitive function in aged rats with memory impairment. Neuropharmacology 2013.

[62] Bakker A, Krauss GL, Albert MS, Speck CL, Jones LR, Stark CE, et al. Reduction of hippocampal hyperactivity improves cognition in amnestic mild cognitive impairment. Neuron 2012;74:467-74.

[63] Pizzarelli R, Cherubini E. Alterations of GABAergic signaling in autism spectrum disorders. Neural Plast 2011;2011:297153.

[64] Mendez MA, Horder J, Myers J, Coghlan S, Stokes P, Erritzoe D, et al. The brain GABAbenzodiazepine receptor alpha-5 subtype in autism spectrum disorder: A pilot [(11)C]Ro154513 positron emission tomography study. Neuropharmacology 2012.

[65] Lemonnier E, Ben-Ari Y. The diuretic bumetanide decreases autistic behaviour in five infants treated during 3 months with no side effects. Acta Paediatr 2010;99:1885-8.

[66] Cai K, Nanga RP, Lamprou L, Schinstine C, Elliott M, Hariharan H, et al. The Impact of Gabapentin Administration on Brain GABA and Glutamate Concentrations: A 7T (1)H-MRS Study. Neuropsychopharmacology 2012.

[67] Simpson HB, Shungu DC, Bender J, Jr., Mao X, Xu X, Slifstein M, et al. Investigation of Cortical Glutamate-Glutamine and gamma-Aminobutyric Acid in Obsessive-Compulsive Disorder by Proton Magnetic Resonance Spectroscopy. Neuropsychopharmacology 2012;37:2684-92.

[68] Chassain C, Bielicki G, Carcenac C, Ronsin AC, Renou JP, Savasta M, et al. Does MPTP intoxication in mice induce metabolite changes in the nucleus accumbens? A (1) H nuclear MRS study. NMR Biomed 2012.

[69] Mohler H. Cognitive enhancement by pharmacological and behavioral interventions: the murine Down syndrome model. Biochem Pharmacol 2012;84:994-9.

[70] Belichenko PV, Masliah E, Kleschevnikov AM, Villar AJ, Epstein CJ, Salehi A, et al. Synaptic structural abnormalities in the Ts65Dn mouse model of Down Syndrome. J Comp Neurol 2004;480:281-98. 


\begin{tabular}{|c|c|c|c|c|c|}
\hline Pharmacological test & $\begin{array}{l}\text { Animal } \\
\text { wild type }\end{array}$ & Dose of $\alpha 5 \mathrm{IA}$ & $\mathrm{p}$ value & Dose of Ro4938581 & $\mathrm{p}$ value \\
\hline \multicolumn{6}{|l|}{ Anxiogenic activity } \\
\hline \multirow[t]{3}{*}{ Elevated Plus Maze } & Rat & $1-10 \mathrm{mg} / \mathrm{kg}$ p.o. ${ }^{1}$ & & $0.3-3 \mathrm{mg} / \mathrm{kg}$ p.o. ${ }^{3}$ & NS \\
\hline & Mouse & $5 \mathrm{mg} / \mathrm{kg}$ i.p. ${ }^{2}$ & $<0.05^{*}$ & & \\
\hline & Mouse & $15 \mathrm{mg} / \mathrm{kg} 2$ weeks $^{2}$ & NS & & \\
\hline Social Approach Avoidance & Rat & & & $0.3-3 \mathrm{mg} / \mathrm{kg} \mathrm{p} . \mathrm{o}^{3}$ & NS \\
\hline \multicolumn{6}{|l|}{ Proconvulsant effects } \\
\hline Threshold of PTZ seizures & Mouse & $10-50 \mathrm{mg} / \mathrm{kg}$ i.p. ${ }^{1,2}$ & NS & & \\
\hline Kindling & Mouse & $10 \mathrm{mg} / \mathrm{kg}$ i.p. 19 days $^{2}$ & NS & & \\
\hline Audiogenic seizures & Mouse & & & up to $100 \mathrm{mg} / \mathrm{kg}^{3}$ & NS \\
\hline \multicolumn{6}{|l|}{ Promnesiant activity } \\
\hline \multirow[t]{3}{*}{ DMTP water maze } & Rat & $0.03-0.3 \mathrm{mg} / \mathrm{kg}$ p.o.5 days ${ }^{1}$ & $<0.005$ & $0.1-10 \mathrm{mg} / \mathrm{kg}^{3}$ & NS \\
\hline & Rat & $0.3-3 \mathrm{mg} / \mathrm{kg}$ p.o. 8 days $^{1}$ & $<0.005$ & & \\
\hline & Mouse & $1,5 \mathrm{mg} / \mathrm{kg}^{2}$ & $<0.05$ & & \\
\hline DMTP after scopolamine & Rat & & & $0.3-1 \mathrm{mg} / \mathrm{kg}^{3}$ & $<0.01$ \\
\hline MWM & Mouse & $1-5 \mathrm{mg} / \mathrm{kg}$ i.p. ${ }^{2}$ & 0.025 & & $<0.01$ \\
\hline MWM on diazepam effect & Rat & & & $1-10 \mathrm{mg} / \mathrm{kg}^{3}$ & $<0.001$ \\
\hline NOR & Mouse & $5 \mathrm{mg} / \mathrm{kg}$ i.p. ${ }^{2}$ & 0.005 & & \\
\hline Object Retrieval Tasks & Monkey & & & $3-10 \mathrm{mg} / \mathrm{kg}^{3}$ & $<0.001$ \\
\hline \multicolumn{6}{|l|}{ Locomotor activity } \\
\hline Rotarod & Mouse & $0.3-10 \mathrm{mg} / \mathrm{kg}$ p.o. ${ }^{1}$ & NS & & \\
\hline Open Field & Mouse & $5 \mathrm{mg} / \mathrm{kg}$ i.p..$^{2}$ & NS & & \\
\hline
\end{tabular}

${ }^{1}[43]^{2}[50]^{3}[47]^{*}$ Due to a normalization of anxiety levels (low to normal) in Ts65Dn mice.

Table 1: Pharmacological profile of the two $\alpha 5$-containing $\mathrm{GABA}_{\mathrm{A}}$ receptors inverse agonists: $\alpha 5$ IA and Ro4938581 


\begin{tabular}{llcc} 
Injected drug & Genotype & Nb of mice with convulsions & Latency to convulsions \\
\hline Vehicle & Euploid & $0 / 6$ & - \\
$\beta$-CCM $3 \mathrm{mg} / \mathrm{kg}$ i.p. & Euploid & $3 / 6$ & $213 \mathrm{sec}$ \\
& & & - \\
Vehicle & Ts65Dn & $0 / 6$ & -
\end{tabular}

Table 2: Effects of the non-selective convulsivant inverse agonist $\beta$-CCM in Ts65Dn and euploid wt mice. 


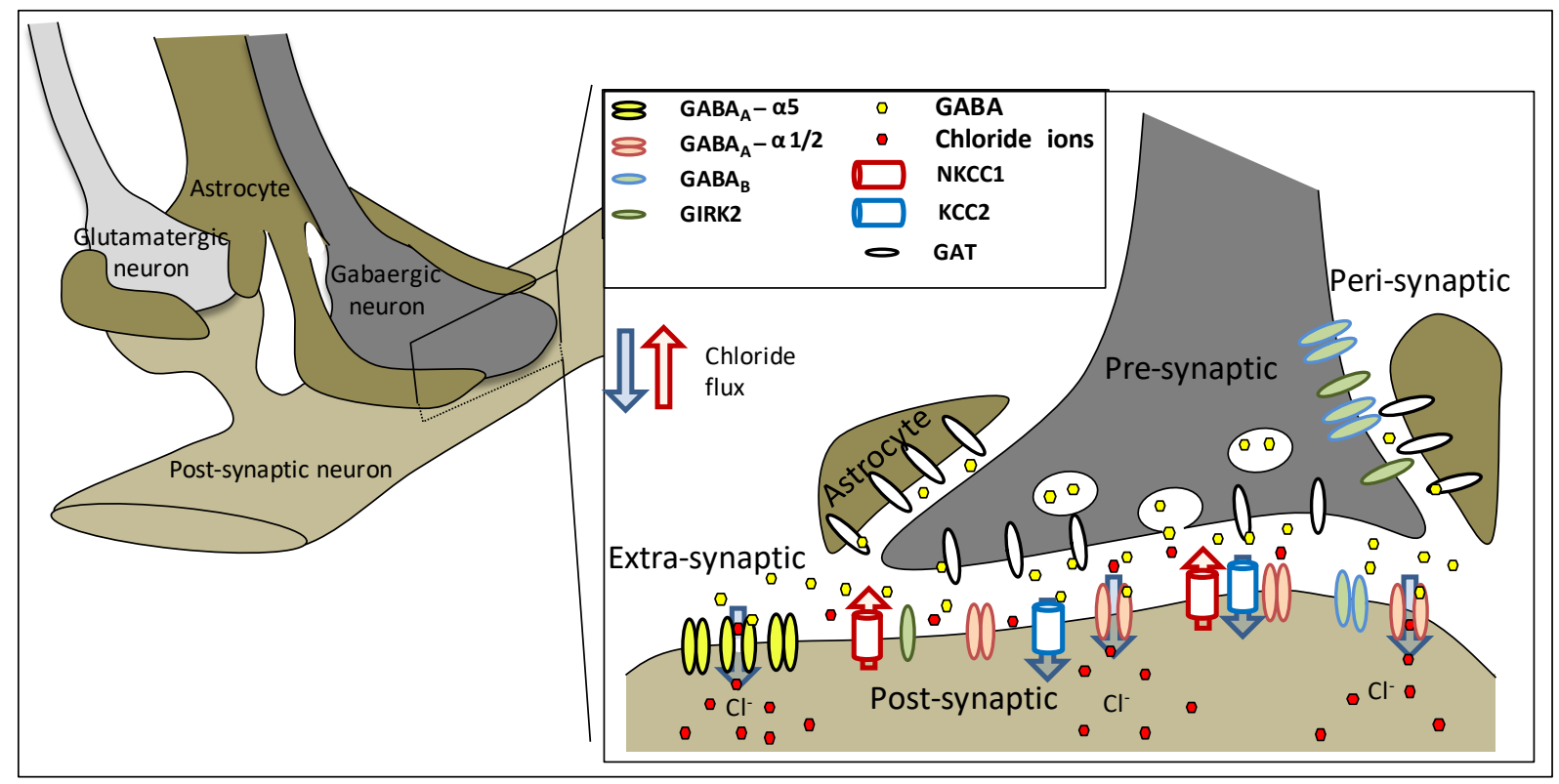

Figure: Mechanisms of GABA inhibition in Down syndrome: increase of the size of inhibitory synapses $[5,17$, 70] could produce more GABA that is not able to be transported through GAT thus producing GABA spillover and the activation of extra-synaptic receptors such as $\alpha 5$-containing $\mathrm{GABA}_{\mathrm{A}}$ receptors. Right part is a magnification of the rectangle on the left part of the figure. 